\title{
Towards a New History of Elite Cultural Expression in Japanese-Occupied China
}

\author{
Jeremy E. Taylor \\ University of Nottingham, Nottingham, UK \\ Jeremy.Taylor@nottingham.ac.uk \\ Zhiyi Yang \\ Goethe University, Frankfurt, Germany \\ z.yang@em.uni-frankfurt.de
}

\begin{abstract}
This paper provides a 'state of the field' view of what the authors refer to as the 'new cultural history' of Japanese-occupied China. It explores how this small but growing field is beginning to provide new perspectives on questions of 'collaboration' and 'resistance' that have dominated many recent studies of wartime China. In addition, the authors argue that more research needs to focus on elite forms of Chinese cultural expression under occupation (a topic which has hitherto eluded serious academic scrutiny). This introduction also introduces the four key papers which make up this special issue.
\end{abstract}

\section{Keywords}

cultural history - occupation - collaboration - accommodation - China - World War II

\section{Introduction: Interpreting World War II Occupation in 2020}

Coming as it did amid a global pandemic, the $75^{\text {th }}$ anniversary of the end of World War II in Europe in 2020 was a far more subdued affair than the commemorations that had marked the end of the same conflict just five years earlier. To be sure, the comparisons that were frequently made in the popular media between wartime mobilisation and the efforts to combat the spread 
of Covid-19 had made the anniversary all the more pertinent. ${ }^{1}$ Yet instead of the overt nationalism that had been a hallmark of 2015 , the more recent anniversary was witness to calls in many parts of the world for global solidarity. ${ }^{2}$ The events and exhibitions condemning wartime 'collaboration' that had typified 2015 were all but forgotten in the context of a global health crisis in 2020. ${ }^{3}$

The years leading up to and immediately following 2015 had arguably marked the most intense period for scholarly reassessment of World War II, particularly in the field of modern Chinese history. Major conferences, projects and exhibitions on the Second Sino-Japanese War were held in 2015 in Taipei and Beijing, for example-many of them reflecting contemporary political concerns as much as historical sensibilities. ${ }^{4}$ In contrast, a number of major scholarly publications that were produced around the same time outside China not only added to our understanding of this conflict, but also complicated our interpretations of it. In some cases, this included a new consideration of the intra-Chinese violence and rivalry that shaped this supposed 'War of Resistance' (kangzhan) against Japan. ${ }^{5}$

A key component of at least some of the resulting scholarship has been a focus on the political, military and social history of those areas of China that were subject to Japanese occupation in the period between 1937 (or 1931, if we include Manchuria) and 1945. Such scholarship built on an earlier body of work that had taken as its focus wartime Chinese collaboration with the Japanese ${ }^{6}$ -

1 Even if such comparisons have been deemed problematic by many scholars. See, for instance, Costanza Musu, 'War metaphors used for coviD-19 are compelling but also dangerous', The Conversation, 8 April 2020; https://theconversation.com/war-metaphors-used-for-covid -19-are-compelling-but-also-dangerous-135406.

2 As expressed in the United Nations' draft resolution on 'Global solidarity to fight Covid-19' on 30 March 2020; https://www.un.org/pga/74/2020/o3/3o/global-solidarity-to-fight-covid-19/.

3 One example being the 'La Collaboration' exhibition held at the Archives nationales in France. See Thomas Fontaine and Denis Peschanski, La Collaboration: Vichy, Paris, Berlin, 1940-1945 (Paris: Éditions Tallandier, 2014).

4 Rana Mitter, 'Presentism and China's changing wartime past', Past and Present 234 (February 2017): $263^{-274}$.

5 As Hans van de Ven has recently suggested, for example, 'The War of Resistance was never about the defeat of Japan alone. For China was at war not just with Japan but also with itself.' See Hans van de Ven, China at War: Triumph and Tragedy in the Emergence of the New China (Cambridge, MA: Harvard University Press, 2017), 4. Other representative publications in English which were published in the lead-up to, during and shortly after 2015 include Peter Harmsen, Shanghai 1937: Stalingrad on the Yangtze (Havertown, PA: Casemate, 2013) and Rana Mitter, Forgotten Ally: China's World War II, 1937-1945 (Boston: Houghton Mifflin, 2013).

6 While it would be impossible to deconstruct the term 'collaboration' here, we acknowledge the debates that surround the term and its usage in the Chinese context. We follow Brook's use of the term 'collaborator' here (i.e. 'those who were actively engaged in promoting the 
a topic that was first seriously explored in the early 1970s, and was fuelled by the publication of the memoirs and diaries of key Chinese collaborators and other sources a decade or more earlier. ${ }^{7}$ To be sure, the 'client regimes's that were financed by the Japanese and staffed by Chinese collaborators in wartime continue to be condemned by some scholars as having had a 'distinctive, seedy character', or as representing a 'cynical bargain' between local elites and the invading Japanese. ${ }^{9}$ Over the last decade or more, however, many historians have started to question such caricatures as they investigate the role of Chinese people in the economic, political, security and social management of Japaneseoccupied China. Thanks to the publication of a number of foundational studies in the early 200os, ${ }^{10}$ as well as an increasing focus on the political economy of the occupation by scholars in the PRC, ${ }^{11}$ we now have a more nuanced view

creation and maintenance of the occupation state'); see Timothy Brook, Collaboration: Japanese Agents and Local Chinese Elites in Wartime China (Cambridge, MA: Harvard University Press, 2005), 13.

7 Two major examples of such scholarship are John Hunter Boyle, China and Japan at War, 1937-1945: The Politics of Collaboration (Stanford, CA: Stanford University Press, 1972) and Gerald E. Bunker, The Peace Conspiracy: Wang Ching-wei and the China War, 19371941 (Cambridge, MA: Harvard University Press, 1972). The primary texts which inspired some of this scholarship include the multi-volume set of Jin Xiongbai's memoirs (published under the pseudonyms Chen Zijia and Zhu Zijia), in Hong Kong in various volumes in the 195os and 196os. See, for example, Zhu Zijia (Jin Xiongbai), Wang zhengquan de kaichang yu shouchang (The Beginning and End of the Wang Regime) (Hong Kong: Chunqiu zazhishe, 1959-1965). Another important source of information for this earlier generation of scholarship was memoirs that had been written by Japanese advisors to the Wang regime.

8 The term 'client regime' is borrowed from David P. Barrett, 'Introduction', in Chinese Collaboration with Japan, 1932-1945: The Limits of Accommodation, eds David P. Barrett and Larry N. Shyu (Stanford, CA: Stanford University Press, 2001), 1-17.

These characterisations are made in Stephen R. MacKinnon, 'Conclusion: wartime China', in China at War: Regions of China, 1937-45, eds Stephen R. MacKinnon, Diana Lary and Ezra Vogel (Stanford, CA: Stanford University Press, 2007), 340.

10 Brian G. Martin, 'Shield of collaboration: the Wang Jingwei regime's security service, 19391945', Intelligence and National Security 16, 4 (2001): 89-148; Wang Ke-wen, 'Irreversible verdict? Historical assessments of Wang Jingwei in the People's Republic and Taiwan', Twentieth-Century China 28, 1 (November 2002): 57-81; Parks M. Coble, Chinese Capitalists in Japan's New Order: The Occupied Lower Yangzi, 1937-1945 (Berkeley: University of California Press, 2003); Brook, Collaboration; Margherita Zanasi, Saving the Nation: Economic Modernity in Republican China (Chicago: University of Chicago Press, 2006).

11 See, for example, Wu Jingping, Kangzhan shiqi de Shanghai jingji (The Shanghai Economy during the War of Resistance) (Shanghai: Shanghai renmin chubanshe, 2001); Huang Meizhen, Ri-wei dui Huazhong lunxianqu jingji de lüeduo yu tongzhi (The Economic Pillage and Control of the Occupied Areas of Central China under the Japanese and the Bogus Regime) (Beijing: Shehui kexue wenxian chubanshe, 2005); Pan Min, Jiangsu Ri-weijiceng 
of life in the 'fallen areas' (lunxianqu). We also have an expanding theoretical toolkit with which to deconstruct discursive categories such as 'Hanjian' (literally, 'traitors [to the Han race]'), and we are beginning to understand how such terms were manipulated and gendered in the postwar struggle to claim control over interpretation of the war and its significance to China. ${ }^{12}$ All of this has continued to encourage a surge of scholarly interest throughout Europe, Asia, North America and Australasia in various aspects of life in wartime China beyond the 'great hinterland' (da houfang). ${ }^{13}$

It is such work that inspired the editors of this special issue to convene a workshop in London in 2019 on the 'cultural and intellectual histories of Japaneseoccupied China'. Our aim was to assess the 'state of the field' in terms of the study of the Japanese occupation of China, but to do so from a decidedly cultural angle. To be sure, the cultural history of Japanese-occupied China is not an entirely untouched realm of research. Edward Gunn Jr's influential book Unwelcome Muse, as well as Poshek Fu's Passivity, Resistance, and Collaboration, published a decade later, both set high standards for the study of cultural production, and particularly literature, in occupied Shanghai and Beijing. ${ }^{14}$ Both these works painted a nuanced picture of cultural production in the context of a belligerent Japanese presence, and both forced the academy to recognise that

zhengquan yanjiu (1937-1945) (A Study of Japanese-Bogus Regime Rule at the Local Level in Jiangsu (1937-1945)) (Shanghai: Shanghai renmin chubanshe, 2006).

12 Frederic Wakeman, Jr, "Hanjian" (Traitor)! Collaboration and retribution in wartime Shanghai', in Becoming Chinese: Passages to Modernity and Beyond, ed. Wen-hsin Yeh (Berkeley: University of California Press, 200o), 298-341; Yun Xia, Down with Traitors: Justice and Nationalism in Wartime China (Seattle: University of Washington Press, 2017).

13 For examples, see Joseph K.S. Yick, "Pre-collaboration”: the political activity and influence of Chen Bijun in wartime China, January 1938-May 1940', Southeast Review of Asian Studies 36 (2014): 58-74; David Serfass, 'L' occupation japonaise comme objet pour l' histoire de l'État chinois: L' exemple de la campagne de pacification rurale du gouvernement de Wang Jingwei, 1941-45' (The Japanese occupation as an object for the history of the Chinese state: the example of the Rural Pacification campaigns of the Wang Jingwei government, 1941-45), Études chinoises 35, 2 (2016): 123-137.

14 Edward M. Gunn, Jr, Unwelcome Muse: Chinese Literature in Shanghai and Peking, 19371945 (New York: Columbia University Press, 1980); Poshek Fu, Passivity, Resistance, and Collaboration: Intellectual Choices in Occupied Shanghai, 1937-1945 (Stanford, CA: Stanford University Press, 1993). 
the occupation did not lead to the complete end of cultural expression, ${ }^{15}$ but rather to new and complex artistic and literary responses to an unprecedented situation - one that included, for some, a rapid shift towards seclusion or nostalgia. Such scholarship also laid the basis for later studies of cinema, popular music, performing arts, graphic art and photography in Japanese-occupied China, ${ }^{16}$ as well as more extensive research on fiction, poetry and other forms of literature. ${ }^{17}$

Despite this nascent scholarship, however, study of occupation-era cultural production remains arguably more contentious than other fields of collaboration. There are many potential reasons for this. It may be, for example, that a focus on cultural production has the potential to open up uncomfortable questions about the innermost thoughts and beliefs of individuals who ended up (to reference a cliché) 'on the wrong side of history' after 1945. To examine how certain persons or groups continued to conduct business or manage law and order under foreign occupation is one thing; to consider the poems, pictures or essays that their peers produced under occupation is quite another-though the scholarship on cognate cases, such as Vichy France, has already shown us how and why this needs to be done. Art has always been a sensitive but important topic for understanding Vichy, argues Laurence Bertrand Dorléac, for example, precisely because it was believed that this field of endeavour could

15 Though it remains the case that some recent studies of China's 'wartime culture' have entirely ignored such research. See, for example, Li Zhongming, Kang-Ri zhanzheng shiqi de Zhongguo wenhua (Chinese Culture in the Era of the War of Resistance) (Beijing: Tuanjie chubanshe, 2015).

16 Examples include Poshek Fu, 'The ambiguity of entertainment: Chinese cinema in Japanese-occupied Shanghai, 1941 to 1945', Cinema Journal 37, 1 (Autumn 1997): 66-84; Shelley Stephenson, 'A star by any other name: the (after) lives of Li Xianglan', Quarterly Review of Film and Video 19, 1 (2002): 1-13; Jiang Jin, 'Dubious prosperity: women and entertainment in wartime Shanghai', Frontiers of History in China 4, 1 (2009): 124-148; Jeremy E. Taylor, 'Cartoons and collaboration in wartime China: the mobilization of Chinese cartoonists under Japanese occupation', Modern China 41, 4 (2015): 406-435; Jeremy E. Taylor, 'The "occupied lens" in wartime China: portrait photography in the service of Chinese "collaboration", 1939-1945', History of Photography 43, 3 (2019): 284-307.

17 See, for instance, Nicole Huang, Women, War, Domesticity: Shanghai Literature and Popular Culture of the 1940s (Leiden and Boston: Brill, 2005); Norman Smith, Resisting Manchukuo: Chinese Women Writers and the Japanese Occupation (Vancouver: Uвс Press, 2007); Liu Wei-Chih, Liang Wang heping yundong xia de fushi yanzhi (Peace Movement: A Discussion on the Classic Poetry of Liang-Wang Et Al [sic.]), PhD dissertation (National Tsinghua University, 2017); Yuan Yidan, Cishi huaibao xiang shei kai (To Whom I Now Reveal My Heart) (Shanghai: Shanghai wenyi chubanshe, 2020); Zhiyi Yang, 'Site: the impossibility of remembering the past in Nanjing', Modern Chinese Literature and Culture 32, 1 (2020): 233-278. 
'ward off the crisis [of occupation] by edifying the multitude and healing their souls. ${ }^{18}$ To discover that art can, in fact, be used by a diverse range of actors and for often conflicting agendas under occupation can still represent an unsettling truth.

For scholars whose main quarry is the aesthetic quality of cultural production, there also remains a lingering sense that art produced under occupation is inferior or less genuine, and hence not worthy of in-depth analysis. As Michael $\mathrm{H}$. Kater argues, for example, 'If the aesthetic, formal, and ethical power of culture thrives on contradiction to prevailing social and political norms ... then it will arguably always fail under tyranny. 19 Such assumptions continue to result in some forms of cultural expression under Japanese occupation being entirely overlooked in the story of the development of specific cultural fields in modern China - almost as if cultural pursuits of any kind stood still in much of east, north and south China between 1937 and $1945 .^{20}$

Perhaps more problematic is the fact that so much of what students are taught today about the development of the People's Republic is based on the 'cultures of resistance' that were developed in the crucible of Yan'an or in 'gudao' (solitary island) Shanghai in the lead-up to, or during, the war. ${ }^{21}$ Writing about cultural production in areas that were occupied by the Japanese and their proxies has largely been ignored in favour of a continued fascination with cultural developments that occurred in wartime China's west or among 'progressive' intellectuals who sought to encourage cultural mobilisation against the Japanese. ${ }^{22}$ Indeed, much of this scholarship appears to assume that it was only (or at least predominantly) those who resisted the Japanese who found in

18 Laurence Bertrand Dorléac, Art of the Defeat: France 1940-1944, translated by Jane Marie Todd (Los Angeles: Getty Research Institute, 2008), 2.

19 Michael H. Kater, Culture in Nazi Germany (New Haven, CT: Yale University Press, 2019), xiv.

20 Many of the major studies of photography in China, for example, simply do not engage with Chinese photography under Japanese occupation, so that the entire period between 1937 and 1945 is not so much as mentioned (except in relation to photography produced outside of the occupied areas). See, for instance, Claire Roberts, Photography and China (Hong Kong: Hong Kong University Press, 2012).

21 Chang-tai Hung, War and Popular Culture: Resistance in Modern China, 1937-1945 (Berkeley: University of California Press, 1994).

22 Such sentiments are prominent in key works such as Stephen R. MacKinnon, Wuhan, 1938: War, Refugees, and the Making of Modern China (Berkeley: University of California Press, 2008), especially pp. 62-65. For a more recent example of such an approach, see Pingchao Zhu, Wartime Culture in Guilin, 1938-1944: A City at War (Lanham, MD: Lexington Books, 2015). 
the arts and culture a means to assert 'human subjectivity and will, ${ }^{23}$ and who produced songs, literature or visual cultures worth studying.

All this has meant that those of us who are interested in the cultural history of Japanese-occupied China 'south of the Great Wall' are only now beginning to catch up with our peers who work on wartime Europe, or those whose focus is Manchuria or other parts of the Japanese empire. ${ }^{24}$ It has also meant that many of us continue to contend with a field that is reticent about acknowledging the very existence of the figures or texts that we study.

Despite such challenges, and the great diversity of studies that have emerged from this recent 'occupation cultural history', a number of key attributes can be identified across this scholarship. For example, rather than ignore occupation culture on the assumption that Chinese cultural workers were not able to explore 'in depth the experiences of ordinary people in wartime', ${ }^{25}$ this new scholarship demonstrates the extent of Chinese cultural agency in spite of extreme levels of censorship and, in some cases, a lack of access to the most basic 'tools of the trade', such as ink or paper. It proves that Chinese writers, artists, filmmakers and performers did manage to express themselves even in the most difficult of circumstances, and that some were able to explore (within strict limitations) questions of Chinese suffering under occupation. ${ }^{26}$ It also focuses on the agony and moral dilemmas faced by those individuals who collaborated directly with the Japanese. Indeed, some recent scholarship has shown that such agency was not limited to cultural workers themselves; even Chinese audiences and consumers living under Japanese occupation were able to imbue the most blatantly propagandistic of occupation-era art with new significance and meaning, undermining both Japanese and collaborationist aspirations for cultural hegemony. ${ }^{27}$

23 Xiaobing Tang, 'Radio, sound cinema, and community singing: the making of a new sonic culture in modern China', Twentieth-century China 45, 1 (2020): 22.

24 A subfield which has always put the cultural history of Japanese occupation at the forefront of its work, with some of the seminal texts in the field being based on this approach. See, for example, Louise Young, Japan's Total Empire: Manchuria and the Culture of Wartime Imperialism (Berkeley: University of California Press, 1998); Smith, Resisting Manchukuo.

25 Carolyn FitzGerald, Fragmenting Modernisms: Chinese Wartime Literature, Art, and Film, 1937-49 (Boston: Brill, 2013), 169 .

26 See, for example, Jeremy E. Taylor, Iconographies of Occupation: Visual Cultures in Wang Jingwei's China, 1939-1945 (Honolulu: University of Hawai'i Press, forthcoming).

27 Some of the most fascinating recent scholarship to emerge in film history, for example, has shown how apparently propagandistic Japanese films, such as Shina no yoru (China Nights) (1940), were transformed into expressions of nostalgia for early 1940 gudao autonomy by middle-class audiences in late-war Shanghai. On this, see Michael Raine, "'You 
The second element of this literature is the tendency to view cultural production in Japanese-occupied China not in opposition to, but in conjunction with, cultural production in other parts of China, be that gudao Shanghai, the 'great hinterland', or the communist base areas. Drawing on developments in cognate fields of scholarship such as economic and business history, ${ }^{28}$ as well as an increasing awareness of the direct links that developed between client regimes and their supposed enemies in China's west, ${ }^{29}$ much of this scholarship stresses the (often clandestine or oblique) dialogue that developed across 'enemy lines' in wartime China-e.g. the movement of people, ideas, products, techniques and tropes across what have hitherto been viewed as untraversable boundaries. ${ }^{30}$ In this regard, such work has raised questions of earlier scholarship that stressed the artistic uniqueness of (particularly communist) 'resistance' culture. For example, we now know that many cultural projects undertaken in the name of revolution in Yan'an or national unity in Chongqing had parallels in occupied Nanjing and Beijing 31 - even if the tendency towards strict cultural proscription that was articulated by Mao Zedong in May 1942 remained a uniquely communist innovation. ${ }^{32}$

The third point, linked to the above, is a rejection of the collaboration/resistance dichotomy that exercised so much earlier scholarship. Indeed, just as research on Vichy has aided a more general shift away from such black-and-

can't replace Gone with the Wind with Chüshingura": China Nights and the problem of Japanese film policy in occupied Shanghai', Film History 30, 2 (Summer 2018): 164-198.

28 Sherman Cochran, 'Marketing medicine across enemy lines: Chinese "fixers" and Shanghai's wartime centrality', in In the Shadow of the Rising Sun: Shanghai under Japanese Occupation, eds Christian Henriot and Wen-hsin Yeh (Cambridge: Cambridge University Press, 2004), 66-89.

29 For an example, see Joseph K.S. Yick, 'Communist-puppet collaboration in Japaneseoccupied China: Pan Hannian and Li Shiqun, 1939-43', Intelligence and National Security 16, 4 (2001): 61-88.

30 See, for example, Allison Rottmann, 'Crossing enemy lines: Shanghai and the Central China Base', in In the Shadow of the Rising Sun: Shanghai under Japanese Occupation, eds Christian Henriot and Wen-hsin Yeh (Cambridge: Cambridge University Press, 2004), 9o110.

31 The creation of something called 'Mao Zedong Thought' finding parallels with 'Wang Jingwei-ism' in occupied Nanjing, for example. On this, see Jeremy E. Taylor, 'Republican personality cults in wartime China: contradistinction and collaboration', Comparative Studies in Society and History 57, 3 (2015): 665-693.

32 To be sure, cultural production in places such as Nanjing and Shanghai was subject to strict censorship, and regulations governing wartime culture were introduced under Wang Jingwei in 1943. The CCP was alone, however, in producing such a lengthy and specific set of guidelines on art and culture in wartime; no collaborationist regime directed its writers and artists to work in only one style, for example. 
white readings of the occupation experience, the new cultural histories of wartime China are showing that such categorisations are difficult to justify. This becomes particularly clear when we examine patterns of elite cultural expression in Japanese-occupied China (as the papers in this special issue all do).

\section{Patterns of Elite Cultural 'Accommodation' and Survival under Occupation}

Despite the significant progress that has been made in the nascent scholarship on occupied Chinese culture history, there are still many areas which remain unexplored. Indeed, it is clear that there are particular media which continue to inspire scholarship on occupation culture, even while others continue to go unnoticed. This can perhaps best be illustrated by the very names which are inevitably invoked when discussion turns to 'cultural collaboration'. The prevalence of individuals such as Eileen Chang (Zhang Ailing 張愛玲), Zhou Zuoren 周作人 and Li Lihua 李麗華 do not represent a scholarly oversight in the extant research. They do, however, point to the dominance of literature and cinema in the scholarship. They also suggest a tendency to choose research topics according to labels that are themselves relics of the war, such as 'wenhua Hanjian' (cultural traitors). ${ }^{33}$ The critical appraisal of such figures remains entirely relevant, and there is still much new primary source material authored or created by such figures that is only becoming available to researchers now. ${ }^{34}$ Yet the emphasis on such 'cultural traitors' has also led to other figures, whose role under occupation is more difficult to categorise, being overlooked. It has also meant that many areas of cultural production beyond modern literature and cinema continue to evade analysis.

One of the aims of this special issue, therefore, is to focus not on these wellestablished 'cultural traitors' but on other, lesser-known figures whose postwar

33 On Zhuo Zuoren, see Susan Daruvala, 'On literature and collaboration', in A New Literary History of Modern China, ed. David Der-wei Wang (Cambridge, MA: Belknap Press/Harvard University Press, 2017), 522-527; on Eileen Chang as a 'cultural traitor', see HsiuChuang Deppman, 'Seduction of a filmic romance: Ang Lee and Eileen Chang', in Eileen Chang: Romancing Languages, Cultures and Genres, ed. Kam Louise (Hong Kong: Hong Kong University Press, 2012), 155-176 (especially p. 158); on Li Lihua, see Yun Xia, 'Engendering contempt for collaborators: anti-Hanjian discourse following the Sino-Japanese War of 1937-1945', Journal of Women's History 25, 1 (2013): 111-134.

34 On such materials, see Zhou Jiyi and Zhou Yiming, 'Historical research materials on Zhou Zuoren in the possession of his family', translated by Susan Daruvala, Bunka ronshü (Tokyo) 55 (September 2019): 47-102. 
reputations were not always sullied by their wartime careers, and who, in some cases, are rarely even associated with collaboration-despite the occupation being a major period of intellectual or artistic development for them. All papers in this issue examine individuals whose relationship with the client regimes that were established by the Japanese was ambivalent.

Drawing on the lexicon of the European historiography, and specifically Philippe Burrin's notion of 'accommodation', ${ }^{35}$ we define some (though by no means all) of the figures who populate this collection as 'elite cultural accommodators'. Such 'accommodators' were well-educated 'men of letters' - and in this issue, as a reflection of the milieu from which most of these individuals emerged, they were indeed men. In almost all cases, these men were well versed in 'elite' forms of cultural pursuit prior to the war, and all continued, for a diverse range of reasons, to practise such forms of expression under Japanese occupation.

In keeping with the general move away from 'one-size-fits-all' categories in the study of the Japanese occupation, however, we also acknowledge that patterns of behaviour exhibited by cultural elites in occupied China were not always so easy to define. Indeed, a number of the figures who emerge from the papers in this collection might better be described as elite 'survivors'-i.e. figures who did not necessarily accommodate with collaborationist regimes, yet who, for reasons of contingency and sometimes even luck, managed to survive the occupation with their reputations and work intact. Others were not so fortunate. Thus, while the cultural elites we examine in this issue differed in many ways from their peers in the mass media, they did not necessarily represent a universal experience that was shared by all 'men of letters' in occupied China.

The focus on culturally elite men that shapes the papers in this collection does not contradict the emerging scholarship on mass culture, 'New Culture' or the (in)famous 'cultural traitors' who are so prevalent in the literature; nor are these papers presented in order to contradict the groundbreaking work of scholars such as Nicole Huang in highlighting the role of the Japanese occupation in opening up new cultural opportunities for educated women in China. ${ }^{36}$ Just as importantly, we acknowledge that not all occupation cultural production can be easily categorised as either 'mass' or 'elite', and that many key cultural workers moved between these two supposedly distinct spheres. As recent scholarship on visual cultures suggests, for example, some artists were just as

35 Philippe Burrin, Living with Defeat:France under the German Occupation (London: Arnold, 1996).

36 Nicole Huang, Women, War, Domesticity. 
happy to publish cartoons in popular pictorials as they were to pen essays on fine arts which appeared in literati journals. ${ }^{37}$

Nonetheless, we argue that the experience of elite cultural figures-poets, painters and scholars-complicates the current reading of client regimes as being predominantly concerned with 'lowbrow' culture that was designed to appeal to war-weary urban audiences. In occupied China, cinema-going, listening to popular music and drawing or appreciating cartoons all occurred concurrently with poetry, painting and scholarship - though the latter group naturally spoke to very different audiences. For this reason, in this special issue, we examine those fields of cultural production that are deeply rooted in Chinese traditions. Many of these cultural forms were, by their very nature, ambivalent, as they were used as a means of expressing pride in Chinese culture while at the same time conforming with the mantra of a shared race and shared [written] language' (tongzhong tongwen) that was so prominent in Japanese propaganda. ${ }^{38}$

Perhaps most importantly, we argue that elite art and literary forms revelled in ambivalence and multiplicity of meaning, and that they therefore have the potential to complicate our understanding of Chinese cultural responses to the Japanese or the client regimes they financed. Indeed, it may precisely be such ambiguity that helps to explain why popular fiction writers and filmmakers were more often labelled 'cultural traitors' in the postwar era, while many traditional literati escaped such condemnation-although the postwar and posthumous reputations of many cultural workers who were once tarnished with the 'traitor' brush have often changed across the years in parallel with shifting political and cultural norms. ${ }^{39}$

To be sure, allegory was just as common a feature of occupation-era cinema as it was of wartime classical-style poetry. Yet forms such as guohua achieved levels of ambivalence that were rarely matched in 'mass culture', be that popular fiction or portrait photography. A painting of a chrysanthemum-an image that could be just as easily interpreted as a reference to the Japanese emperor as an expression of Chinese nostalgia - held a far wider array of potential readings than a film or a serialised novel printed in one of the many glossy periodicals sponsored by the Japanese.

37 Taylor, Iconographies of Occupation.

38 Smith, Resisting Manchukuo, 5 .

39 As has been the case for many of the above-mentioned examples, such as Eileen Chang and Zhou Zuoren. 
It is therefore our assertion that a focus on different forms of cultural production - many of which have been hitherto ignored or dismissed in the academic literature-as well as very different genres within those cultural forms, can lead to new interpretations of the wartime experience in occupied China. One example of these is what might be called the 'rise and fall paradigm'. As Timothy Brook argues, collaboration is viewed as a special crime in an era of nationalism, based on the rather modern idea that an individual could collaborate with a nation. ${ }^{41}$ Direct foreign rule can never be fully legitimised, so local collaborators are recruited to give the new order that emerges through occupation some facade of legitimacy. Such an interpretation, however, can be contrasted to traditional Chinese historiography, which featured a cyclical view of history. In this view, all powerful dynasties would inevitably fall, and conquests, including even those led by ethnically foreign powers, were understood as representing a change of 'Heaven's Mandate' (tianming). An individual who had made a career under one dynasty would be morally obliged to refuse an appointment in a new dynasty that had been established under a conqueror, and would thereby become a 'remnant loyalist' (yimin). ${ }^{42}$ In becoming a remnant loyalist, however, such individuals did not necessarily deny the legitimacy of their new rulers. ${ }^{43}$

As the papers by Yuan, Chiu and Yang in this special issue all point out, especially in the early months and years of the Japanese occupation, many Chinese men of letters wondered if the new order that had been introduced by the Japanese would come to represent another case of the 'rise and fall' of dynasties that had occurred many times in China's long history. Indeed, as Timothy

40 Some of the authors of papers in this special issue have chosen to use Chinese characters throughout their papers, while others have provided Chinese characters only for personal names and direct citations in the main text of their papers.

Timothy Brook, 'Hesitating before the judgment of history', The Journal of Asian Studies 71, 1 (2012): 104 .

42 On the difficulty of translating the term 'yimin', as well as the term's links to concepts such as 'loyalty, remnant status, collaboration, eremitism, martyrdom, and migration', see Chien-hsin Tsai, A Passage to China: Literature, Loyalism, and Colonial Taiwan (Boston: Brill, 2017), especially pp. 281-282.

43 There is a significant literature on the role of such 'remnant loyalists' following the fall of the Ming Dynasty. See, for example, Frederic Wakeman Jr, 'Romantics, stoics, and martyrs in seventeenth-century China', Journal of Asian Studies 43, 4 (1984): 631-665; see also Jonathan Hay, 'Posttraumatic art: painting by remnant subjects of the Ming', in The Artful Recluse: Painting, Poetry, and Politics in Seventeenth-century China, eds Peter C. Sturman and Susan S. Tai (Santa Barbara, CA: Santa Barbara Museum of Art, 2012), 77-93. 
Brook has noted, comparisons between Japan's invasion of China in 1937 and the rise of the Qing Dynasty in the seventeenth century were made not only by local elites in some parts of wartime China, but even by the Japanese. ${ }^{44}$ Despite the nationalist awareness of cultural elites under Japanese occupation, then, China's historical memory continued to shape the psychological responses of these individuals to the Japanese presence. Many cultural elites styled themselves as yimin who were mentally disengaged from the politics of the day while they observed the fall of one dynasty and the rise of another or, in the case examined by Zhiyi Yang in this journal, a ranking collaborator who assumed such a passive role in the collaborationist regime that his behaviour and mindset bore great resemblance to those of accommodators. Chiu Yi-hsuan's paper investigates the 'esoteric writing' in the poetry of Qu Xuanying 篗宣穎, a man of letters marginally associated with the collaborationist regime in north China; as Chiu points out, 'esoteric writing' enabled Qu to use a vast array of historical allusions to reflect (in nuanced and complex ways) on the nature of the Japanese occupation for a literati Chinese audience, without necessarily having his work subject to official censorship. Pedith Chan examines the cultural lives of traditional-style (guohua) painters in occupied Shanghai, including those who benefited from the patronage of the Wang Jingwei 汪精衛 regime but were not considered collaborators, and did not suffer from postwar political prosecution; as Chan notes, many painters continued their craft under occupation for a host of reasons. Finally, Yuan Yidan explores the special rhetorical mechanism of allegorical historiography employed in the scholarship of the north China-based historian Chen Yuan 陳垣, who continued to work at Fu Jen University in Beiping (now Beijing) ${ }^{45}$ under occupation. In all cases, regardless of the individuals' patriotism (or lack thereof), living under occupation entailed inescapable ethical perils. Elite forms of cultural expression offered a means of coping with the dilemmas that occupation created.

44 This point is made in Timothy Brook, 'The pacification of Jiading', in Scars of War: The Impact of Warfare on Modern China, eds Diana Lary and Stephen MacKinnon (Vancouver: UBC Press, 2001), especially pp. 6o-61.

45 The city that we now know as Beijing (literally, 'northern capital') was called Beiping (literally, 'northern peace') under the Nationalist Chinese government from 1928 through until the foundation of the People's Republic of China in 1949 (when it was renamed Beijing). However, the city was also called Beijing by the Japanese after the Japanese invasion of it in 1937, and officially retained this name through until 1940, when the Wang Jingwei regime renamed it Beiping (although, in practice, many collaborationist officials and Japanese in the city itself continued to use the name Beijing through until the end of the war, and against the wishes of the Wang regime). Hence, during the Second Sino-Japanese War, the city went by two different (and rival) toponyms. 
To be sure, we do not claim that the papers in this special issue represent a comprehensive coverage of all forms of cultural production in Japaneseoccupied China. Nor are we suggesting that the earlier focus on cinema or literature is misplaced or unimportant. All of the papers in this volume are, to some extent, shaped by this earlier scholarship. We also recognise that some fields of cultural production have not been covered in this issue, and continue to evade academic analysis. For example, many forms of music under Japanese occupation remain, as yet, completely unstudied. Sculpture has been virtually untouched, despite the fact that (as Pedith Chan shows in this special issue) a handful of sculptors such as Zhang Chongren 張充仁 (1907-1998) did continue (even in extremely limited ways) to ply their trade in China, ${ }^{46}$ and despite the uses of sculpture in the political culture of the client regimes. ${ }^{47}$ Western-style oil painting under occupation (though also touched upon by Pedith Chan in her paper for this issue), also remains something of a 'blank canvas', despite the central role of one of the leading exponents of this art form in China, Fang Junbi 方君璧, in becoming a key figure in Wang Jingwei's coterie of followers, and continuing to produce and exhibit her work during the occupation. ${ }^{48} \mathrm{Sim}-$ ilarly, the rapid reconstruction of towns and cities in east China following the Japanese invasion and the subsequent installation of client regimes, as documented in the emerging scholarship in urban history, ${ }^{49}$ suggests the potential for further studies of 'occupation architecture'. This is a field which, as far as the editors of this issue are aware, remains entirely unstudied.

Perhaps more importantly, one area of cultural production which has largely escaped the wholesale attention of the academy is that which is neither 'elite' nor 'mass', but which might broadly be defined as 'folk culture' (minjian wen$h u a$ ). This includes songs, stories, visual arts and dramatic and performance traditions that continued to be practised in occupied rural China (and, of course, by rural people who moved to occupied urban areas as refugees) despite the violence and dislocation caused by the Rural Pacification (qingxiang) campaigns. ${ }^{50}$

46 Tao Kangde and Qiu Shimu, Shenbao nianjian (The Shenbao Almanac) (Shanghai: Shenbaoshe, 1944), 1020-1021.

47 On the production of busts of Wang Jingwei, for example, see Taylor, 'Republican personality cults in wartime China'.

48 Though this is, at least, hinted at in Frank Dunand (ed.), The Pavilion of Marital Harmony: Chinese Painting and Calligraphy between Tradition and Modernity (Geneva: Collections Baur, 2002).

49 On this, see Toby Lincoln, 'The rural and urban at war: invasion and reconstruction in China during the anti-Japanese War of Resistance', Journal of Urban History 20, 10 (2012): $1-19$.

$5^{\circ} \quad$ To be sure there have been a small number of studies of traditional Chinese performing 
This reference to rural China also highlights the geographic limitations of this special issue, and of much of the existing scholarship to date. It is not just rural China which has escaped analysis thus far, but also major centres of cultural production which remained firmly within the occupied zones for most of the war, Guangzhou, Wuhan and Tianjin all being examples. If, therefore, this issue continues a tendency to focus on Beijing, Shanghai and Nanjing, it does so in the full knowledge that more needs to be done on various other parts of occupied China.

Nonetheless, this issue marks an important step in widening our understanding of Chinese cultural expression under Japanese occupation, and it is perhaps fitting that such a step is being taken in the very same fora in which a number of key texts on the political and military history of the Japanese occupation have appeared. ${ }^{51}$ It is our hope that the focus on elite forms of Chinese culture in this collection of papers will not only provoke a renewed interest in the occupation more generally, but that it might also take what we call the 'new cultural history' of occupation into exciting new directions.

\section{Acknowledgments}

Some of the research for this paper was undertaken through the сотсA Project and received funding from the European Research Council (ERC) under the European Union's Horizon 2020 research and innovation programme (Grant Number 682081). The Introduction is based on discussions held following the ERC-funded workshop 'Cultural and Intellectual Histories of Japanese-occupied China', held at Asia House in London on 16 September 2019; the authors thank all participants at that workshop for comments and suggestions during that event, and Asia House for hosting the event. In addition, we thank the Wissenschaftskolleg zu Berlin for hosting the two authors as they planned this jointly authored Introduction, and the anonymous reviewers for their valuable comments and suggestions on earlier drafts.

arts (xiqu), such as Jiang Jin's work on Yueju in Shanghai: Jiang Jin, 'Dubious prosperity: women and entertainment in wartime Shanghai'. However, there are very few studies that look in any depth at other (including more regional) forms of performing art in occupied China.

51 Such as Brian G. Martin, “'In my heart I opposed opium”: opium and the politics of the Wang Jingwei government, 1940-45’. European Journal of East Asian Studies 2, 2 (2003): 365-410. 


\section{References}

Barrett, David P. 'Introduction'. In Chinese Collaboration with Japan, 1932-1945: The Limits of Accommodation. Edited by David P. Barrett and Larry N. Shyu (Stanford, CA: Stanford University Press, 2001), 1-17.

Bertrand Dorléac, Laurence. Art of the Defeat: France 1940-1944. Translated by Jane Marie Todd (Los Angeles: Getty Research Institute, 2008).

Boyle, John Hunter. China and Japan at War, 1937-1945: The Politics of Collaboration (Stanford, CA: Stanford University Press, 1972).

Brook, Timothy. 'The pacification of Jiading'. In Scars of War: The Impact of Warfare on Modern China. Edited by Diana Lary and Stephen MacKinnon (Vancouver: UBC Press, 2001), 50-74.

Brook, Timothy. Collaboration: Japanese Agents and Local Chinese Elites in Wartime China (Cambridge, MA: Harvard University Press, 2005).

Brook, Timothy. 'Hesitating before the judgment of history'. The Journal of Asian Studies 71, 1 (2012): 103-114.

Bunker, Gerald E. The Peace Conspiracy: Wang Ching-wei and the China War, 1937-1941 (Cambridge, MA: Harvard University Press, 1972).

Burrin, Philippe. Living with Defeat: France under the German Occupation (London: Arnold, 1996).

Coble, Parks M. Chinese Capitalists in Japan's New Order: The Occupied Lower Yangzi, 1937-1945 (Berkeley: University of California Press, 2003).

Cochran, Sherman. 'Marketing medicine across enemy lines: Chinese "fixers" and Shanghai's wartime centrality'. In In the Shadow of the Rising Sun: Shanghai under Japanese Occupation. Edited by Christian Henriot and Wen-hsin Yeh (Cambridge: Cambridge University Press, 2004), 66-89.

Daruvala, Susan. 'On literature and collaboration'. In A New Literary History of Modern China. Edited by David Der-wei Wang (Cambridge, MA: Belknap Press/Harvard University Press, 2017), 522-527.

Deppman, Hsiu-Chuang. 'Seduction of a filmic romance: Ang Lee and Eileen Chang'. In Eileen Chang: Romancing Languages, Cultures and Genres. Edited by Kam Louise (Hong Kong: Hong Kong University Press, 2012), 155-176.

Dunand, Frank (ed.). The Pavilion of Marital Harmony: Chinese Painting and Calligraphy between Tradition and Modernity (Geneva: Collections Baur, 2002).

FitzGerald, Carolyn. Fragmenting Modernisms: Chinese Wartime Literature, Art, and Film, 1937-49 (Boston: Brill, 2013).

Fontaine, Thomas, and Denis Peschanski. La Collaboration: Vichy, Paris, Berlin, 19401945 (Paris: Éditions Tallandier, 2014).

Fu, Poshek. Passivity, Resistance, and Collaboration: Intellectual Choices in Occupied Shanghai, 1937-1945 (Stanford, CA: Stanford University Press, 1993). 
Fu, Poshek. 'The ambiguity of entertainment: Chinese cinema in Japanese-occupied Shanghai, 1941 to 1945. Cinema Journal 37, 1 (Autumn 1997): 66-84.

Gunn, Edward M. Jr. Unwelcome Muse: Chinese Literature in Shanghai and Peking, 19371945 (New York: Columbia University Press, 1980).

Harmsen, Peter. Shanghai 1937: Stalingrad on the Yangtze (Havertown, PA: Casemate, 2013).

Hay, Jonathan. 'Posttraumatic art: painting by remnant subjects of the Ming'. In The Artful Recluse: Painting, Poetry, and Politics in Seventeenth-century China. Edited by Peter C. Sturman and Susan S. Tai (Santa Barbara, CA: Santa Barbara Museum of Art, 2012), 77-93.

Huang Meizhen. Ri-wei dui Huazhong lunxianqu jingji de lüeduo yu tongzhi (The Economic Pillage and Control of the Occupied Areas of Central China under the Japanese and the Bogus Regime) (Beijing: Shehui kexue wenxian chubanshe, 2005).

Huang, Nicole. Women, War, Domesticity: Shanghai Literature and Popular Culture of the 1940 (Leiden and Boston: Brill, 2005).

Hung, Chang-tai. War and Popular Culture: Resistance in Modern China, 1937-1945 (Berkeley: University of California Press, 1994).

Jiang Jin. 'Dubious prosperity: women and entertainment in wartime Shanghai'. Frontiers of History in China 4, 1 (2009): 124-148.

Kater, Michael H. Culture in Nazi Germany (New Haven, CT: Yale University Press, 2019).

Li Zhongming. Kang-Ri zhanzheng shiqi de Zhongguo wenhua (Chinese Culture in the Era of the War of Resistance) (Beijing: Tuanjie chubanshe, 2015).

Lincoln, Toby. 'The rural and urban at war: invasion and reconstruction in China during the anti-Japanese War of Resistance'. Journal of Urban History 20, 10 (2012): $1-19$.

Liu Wei-Chih. Liang Wang hepingyundong xia de fushiyanzhi (Peace Movement: A Discussion on the Classic Poetry of Liang-Wang Et Al [sic.]). PhD dissertation (National Tsinghua University, 2017).

MacKinnon, Stephen R. 'Conclusion: wartime China'. In China at War: Regions of China, 1937-45. Edited by Stephen R. MacKinnon, Diana Lary and Ezra Vogel (Stanford, CA: Stanford University Press, 2007), 335-351.

MacKinnon, Stephen R. Wuhan, 1938: War, Refugees, and the Making of Modern China (Berkeley: University of California Press, 2008).

Martin, Brian G. 'Shield of collaboration: the Wang Jingwei regime's security service, 1939-1945'. Intelligence and National Security 16, 4 (2001): 89-148.

Martin, Brian G. "In my heart I opposed opium": opium and the politics of the Wang Jingwei government, 1940-45'. European Journal of East Asian Studies 2, 2 (2003): 365-410.

Mitter, Rana. Forgotten Ally: China's World War II, 1937-1945 (Boston: Houghton Mifflin, 2013). 
Mitter, Rana. 'Presentism and China's changing wartime past'. Past and Present 234 (February 2017): 263-274.

Musu, Costanza. 'War metaphors used for COVID-19 are compelling but also dangerous'. The Conversation, 8 April 2020; https://theconversation.com/war-metaphors-used -for-covid-19-are-compelling-but-also-dangerous-135406.

Pan Min. Jiangsu Ri-wei jiceng zhengquan yanjiu (1937-1945) (A Study of JapaneseBogus Regime Rule at the Local Level in Jiangsu (1937-1945)) (Shanghai: Shanghai renmin chubanshe, 2006).

Raine, Michael. "You can't replace Gone with the Wind with Chüshingura”: China Nights and the problem of Japanese film policy in occupied Shanghai'. Film History 30,2 (Summer 2018): 164-198.

Roberts, Claire. Photography and China (Hong Kong: Hong Kong University Press, 2012).

Rottmann, Allison. 'Crossing enemy lines; Shanghai and the Central China Base'. In In the Shadow of the Rising Sun: Shanghai under Japanese Occupation. Edited by Christian Henriot and Wen-hsin Yeh (Cambridge: Cambridge University Press, 2004), 9o-110.

Serfass, David. 'L' occupation japonaise comme objet pour l' histoire de l'État chinois: L'exemple de la campagne de pacification rurale du gouvernement de Wang Jingwei, 1941-45' (The Japanese occupation as an object for the history of the Chinese state: the example of the Rural Pacification campaigns of the Wang Jingwei government, 1941-45). Études chinoises 35, 2 (2016): 123-137.

Smith, Norman. Resisting Manchukuo: Chinese Women Writers and the Japanese Occupation (Vancouver: UBC Press, 2007).

Stephenson, Shelley. 'A star by any other name: the (after) lives of Li Xianglan'. Quarterly Review of Film and Video 19, 1 (2002): 1-13.

Tang, Xiaobing. 'Radio, sound cinema, and community singing: the making of a new sonic culture in modern China'. Twentieth-century China 45, 1 (2020): 3-24.

Tao Kangde and Qiu Shimu. Shenbao nianjian (The Shenbao Almanac) (Shanghai: Shenbaoshe, 1944).

Taylor, Jeremy E. 'Cartoons and collaboration in wartime China: the mobilization of Chinese cartoonists under Japanese occupation'. Modern China 41, 4 (2015): 406435 .

Taylor, Jeremy E. 'Republican personality cults in wartime China: contradistinction and collaboration'. Comparative Studies in Society and History 57, 3 (2015): 665693.

Taylor, Jeremy E. "The "occupied lens" in wartime China: portrait photography in the service of Chinese "collaboration", 1939-1945'. History of Photography 43, 3 (2019): 284-307.

Taylor, Jeremy E. Iconographies of Occupation: Visual Cultures in Wang Jingwei's China, 1939-1945 (Honolulu: University of Hawai'i Press, forthcoming). 
Tsai, Chien-hsin. A Passage to China: Literature, Loyalism, and Colonial Taiwan (Boston: Brill, 2017).

United Nations. Draft resolution on 'Global solidarity to fight Covid-19', 30 March 2020; https://www.un.org/pga/74/2020/o3/3o/global-solidarity-to-fight-covid-19/.

van de Ven, Hans. China at War: Triumph and Tragedy in the Emergence of the New China (Cambridge, MA: Harvard University Press, 2017).

Wakeman, Frederic Jr. 'Romantics, stoics, and martyrs in seventeenth-century China'. Journal of Asian Studies 43, 4 (1984): 631-665.

Wakeman, Frederic Jr. "Hanjian" (Traitor)! Collaboration and retribution in wartime Shanghai'. In Becoming Chinese: Passages to Modernity and Beyond. Edited by Wenhsin Yeh (Berkeley: University of California Press, 2000), 298-341.

Wang Ke-wen. 'Irreversible verdict? Historical assessments of Wang Jingwei in the People's Republic and Taiwan'. Twentieth-Century China 28, 1 (November 2002): 57-81.

Wu Jingping. Kangzhan shiqi de Shanghai jingji (The Shanghai Economy during the War of Resistance) (Shanghai: Shanghai renmin chubanshe, 2001).

Yang, Zhiyi. 'Site: the impossibility of remembering the past in Nanjing'. Modern Chinese Literature and Culture 32, 1 (2020): 233-278.

Yick, Joseph K.S. 'Communist-puppet collaboration in Japanese-occupied China: Pan Hannian and Li Shiqun, 1939-43'. Intelligence and National Security 16, 4 (2001): 6188.

Yick, Joseph K.S. “Pre-collaboration”: the political activity and influence of Chen Bijun in wartime China, January 1938-May 1940'. Southeast Review of Asian Studies 36 (2014): 58-74.

Young, Louise. Japan's Total Empire: Manchuria and the Culture of Wartime Imperialism (Berkeley: University of California Press, 1998).

Yuan Yidan. Cishi huaibao xiang shei kai (To Whom I Now Reveal My Heart) (Shanghai: Shanghai wenyi chubanshe, 2020).

Xia, Yun. 'Engendering contempt for collaborators: anti-Hanjian discourse following the Sino-Japanese War of 1937-1945'. Journal of Women's History 25, 1 (2013): 111-134.

Xia, Yun. Down with Traitors: Justice and Nationalism in Wartime China (Seattle: University of Washington Press, 2017).

Zanasi, Margherita. Saving the Nation: Economic Modernity in Republican China (Chicago: University of Chicago Press, 2006).

Zhou Jiyi and Zhou Yiming. 'Historical research materials on Zhou Zuoren in the possession of his family'. Translated by Susan Daruvala. Bunka ronshū (Tokyo) 55 (September 2019): 47-102.

Zhu, Pingchao. Wartime Culture in Guilin, 1938-1944: A City at War (Lanham, MD: Lexington Books, 2015).

Zhu Zijia (Jin Xiongbai). Wang zhengquan de kaichang yu shouchang (The beginning and end of the Wang regime) (Hong Kong: Chunqiu zazhishe, 1959-1965). 